Egyptian Poultry Science Journal

http://www.epsj.journals.ekb.eg/

ISSN: 1110-5623 (Print) - 2090-0570 (Online)

EFFECTS OF SELECTION FOR INCREASING EARLY GROWTH RATE ON GROWTH AND CARCASS CHARACTERISTICS OF JAPANESE QUAIL

D. A. M. Semida ${ }^{1}$, B. Y. F. Mahmoud ${ }^{1}$, E. A. El-Full ${ }^{1}$ and A. M. Emam ${ }^{1,2}$

${ }^{1}$ Fac. of Agric., Poult.Prod. Dep.t, Fayoum Uni., 63514 Fayoum, Egypt.

${ }^{2}$ Corresponding author: Ahmed M Emam Email: ame04@fayoum.edu.eg

Received: 24/11/2019

Accepted: $18 / 12 / 2019$

\begin{abstract}
This study aimed to investigate the effects of selection for high early growth rate during 1-21 days of age $\left(\mathrm{GR}_{1-21}\right)$ on growth traits, some plasma constituent and carcass characteristics. An experiment was carried out at the farm of the Poultry Research Center, Faculty of Agriculture, Fayoum University and continued for six generations including 10,024 for two lines (the selected line, $\mathrm{HGR}_{1-21}$ and the control line, CL) of Japanese quail chicks. The $\mathrm{HGR}_{1-21}$ had better $\mathrm{BW}_{21}, \mathrm{BW}_{35}, \mathrm{GR}_{1-21}, \mathrm{GR}_{1-35}$ and $\mathrm{BWG}_{1-35}$ than the CL. Generation of selection significantly affected all growth traits. Females had significantly higher $\mathrm{BW}_{21}, \mathrm{BW}_{35}, \mathrm{BWG}_{1-35}$ and $\mathrm{GR}_{1-35}$ than males.

Quails of HGR ${ }_{1-21}$ had lower high density lipoprotein (HDL) and higher triglycerides (TG) than the CL. Females had higher TG and lower HDL than males. Quails of HGR 1 21 had higher carcass \%, dressing \%, weights of giblets, heart, gizzard and liver than CL by $3.65 \%, 2.59,23.79,68.42,13.21$ and $23.47 \%$, respectively. Females had higher weights of giblets, gizzard and liver than males by $+12.41 \%, 14.64 \%$ and $12.34 \%$, respectively. The $\mathrm{HGR}_{1-21}$ had higher ether extract \% $(+24.28 \%)$ and lower moisture\% $(-4.79 \%)$ than the CL. GR G-21 $_{1}$ showed moderate heritability $\left(\mathrm{h}^{2}\right)$ of 0.28 and ranged from 0.20 to 0.29 for growth traits. The $\mathrm{GR}_{1-21}$ found to be positively genetic and phenotypic correlated $\left(\mathrm{r}_{\mathrm{g}} \& \mathrm{r}_{\mathrm{p}}\right.$ ) with $\mathrm{BW}_{21}, \mathrm{BW}_{35}, \mathrm{BWG}_{1-35}$ and $\mathrm{GR}_{1-35}$, with $\mathrm{r}_{\mathrm{g}}$ ranged from moderate to high $(0.24$ to 0.70$)$ and $r_{p}$ ranged from low to medium (0.03 to 0.41$)$, however there were negative $r_{g}$ and $r_{p}$ between $G_{1-21}$ and $\mathrm{BW}_{1}$ being -0.15 and 0.50 ,respectively. Genetic response showed superiority of the selected line than the control $(P<0.05)$ for selection criteria $(+0.04)$. Selection for $\mathrm{GR}_{1-21}$ had desired genetic gain with all studied growth traits, except $\mathrm{BW}_{1}$. Also, carcass traits and vital organs were improved due to selection for $\mathrm{GR}_{1-21}$.
\end{abstract}

Key words: selection, early growth rate, carcass characteristics, genetic gain and Japanese quail. 


\section{A. M. Semida ${ }^{1}$ et al.}

\section{INTRODUCTION}

Selection for increasing body weight increased feed consumption, rate of metabolism and leads to higher $\mathrm{O}_{2}$ demand, augmented muscle mass (especially breast muscle) has not been correlated with a relatively increment in vital organs such as the heart and lungs (Havenstein et al., 2003). Moreover, increasing incidence of ascites syndrome arises from consecutive high body weight selection programs in broilers failing to meet the accelerating demand for $\mathrm{O}_{2}$ in their bodies due to imbalance between cardiopulmonary system output and the requires of the body (Druyan et al., 2007). Several problems, such as skeletal abnormalities, massive fat deposition and sudden death syndrome occurred due to intensive application of genetic improvement for body weight and slaughter characteristics of poultry (Narinc and Aksoy, 2012). Growth rate is a biometric trait of moderate to high heritability and can be rapidly improved through selection (Anthony et al., 1991). Either short or long term selection for growth rate resulted in increasing overall body weight at marketing age, body weight at sexual maturity, body protein and skeletal muscles (Reddish, 2004). Selection for growth is associated with change in hormone concentration such as growth hormone and thyroxin (Peebles and Marks, 1991) due to physiological role of liptin in growth regulation by controlling food intake and thermo genesis through actions on hypothalamic centers as well as its role in energy expenditure and maturity (Tartaglia et al., 1995). There were positive genetic correlations among growth rate and both body weights at different ages and growth rate during different periods of growth, therefore indirect selection could be used to enhance these traits (Abdel Fattah, 2006 and Manaa et al., 2015). Several selection investigates have been conducted on live body weight in Japanese quail, however few studies examining early growth rate therefore this study aimed to investigate the influence of selection for early high growth rate of quail on body weight, carcass and some blood constituents.

\section{MATERIALS AND METHODS}

This work was carried out at the farm of the Poultry Research Center, Faculty of Agriculture, Fayoum University. An experiment was continued for six generations (pre-base, base and four selected generations) including 10,024 Japanese quail (Coturnix coturnix japonica) chicks. The selected breeders were housed (two females were randomly assigned to each male) in breeding cages. Matings of close relatives were avoided to decrease the rate of inbreeding depression. Eggs were daily collected in a pedigree system for each family depending on the shell color and patterns of each female when ages of females were 11-14 weeks of age. The newly hatched chicks were wing banded using small size plastic bands, chicks were brooded on the floor until 35 days of age. According to NRC (1994), all quails from hatch to 35 days of age were fed ad libitum on a starter diet containing $24 \%$ crude protein and $2900 \mathrm{~K} \mathrm{Cal} \mathrm{ME}$ and . All chicks were weekly individually weighed to calculate growth rate. From 42 days of age to the end of the study, a breeder diet containing $20 \%$ crude protein, $2900 \mathrm{~K} \mathrm{Cal} \mathrm{ME,} 2.25 \%$ calcium and $0.43 \%$ available phosphorous was supplied. Birds were in continuous light during the first 35 days of age and then reduced to $16 \mathrm{~h}$ of light per day thereafter. Birds were kept under the 
selection, early growth rate, carcass characteristics, genetic gain and Japanese quail.

same managerial hygienic and environmental conditions. At the fourth generation, a slaughter test was performed at 35 days of age using 25 chicks per sex within each line, which were randomly selected for whole body carcass analysis and all giblets were separately weighed. Carcass composition was analyzed in the Laboratory of the Poultry Production Department, Faculty of Agriculture, Fayoum University. Lipid content was measured by ether extraction. Protein content was determined as by $\mathrm{N}$ Kjeldahl x 6.25. About three $\mathrm{cm}^{3}$ of blood samples from each chick were collected during slaughtering into dry clean centrifuge tubes containing one drop of heparin and immediately centrifuged at $3000 \mathrm{rpm}$ for 20 minutes. The clear plasma samples were carefully drawn and transferred to dry, clean, small glass bottles and stored at $-20{ }^{\circ} \mathrm{C}$ in a deep freezer until the time of chemical analyses. Plasma samples were assayed for total cholesterol (mg/dl), high density lipoprotein (HDL, mg/dl), low density lipoprotein (LDL, $\mathrm{mg} / \mathrm{dl})$ and triglycerides ( $\mathrm{TG}, \mathrm{mg} / \mathrm{dl}$ ) by enzymatic colorimetric tests using commercial kits (STANBIO) according to the manufacturer's recommendations.

\section{Selection Program}

Aggregated breeding values of a selection criterion were estimated in two lines of Japanese quail that were simultaneously bred. The selected line for high growth rate during 1-21 days of age ( $\left.\mathrm{HGR}_{1-21}\right)$ was selected according to the estimated aggregated breeding values for four successive generations, while a control line (CL) was kept under random mating without selection.

\section{Studied Traits}

\section{Selection criteria:}

Growth rate during the period from 1-21 days of age $\left(\mathrm{GR}_{1-21}\right)$ was calculated according to Brody (1945) as the following formula:

$\mathrm{GR}=\left[\mathrm{W}_{2}-\mathrm{W}_{1} /{ }^{1} / 2\left(\mathrm{~W}_{2}+\mathrm{W}_{1}\right)\right]$ where: $\mathrm{w}_{1}$ : the weight at the beginning and $w_{2}$ : is the weight at the end of the period.

Also, Growth rate during the period from 1-35 days of age $\left(\mathrm{GR}_{1-35}\right)$ was calculated.

\section{Body weight at different ages:}

Body weight at hatch, 21 and 35 days of age $\left(\mathrm{BW}_{1}, \mathrm{BW}_{21}\right.$ and $\mathrm{BW}_{35}$, respectively) were individually recorded to the nearest $0.01 \mathrm{~g}$.

Body weight gain during the period from 1-35 days of age (BWG $1-35)$ :

According to the following formula BWG $_{1-35}$ was calculated.

$\mathrm{BWG}_{1-35}=\mathrm{BW}_{35}-\mathrm{BW}_{1}$

\section{Slaughter traits:}

Carcasses\%: (100 X Carcass weight / $\left.\mathrm{BW}_{35}\right)$.

Dressing \% was determined: ((Carcass weight + Giblets) / BW 35$)$ X 100.

BLM \% : ((Carcass weight - bones weight) / BW 35 ) X 100

\section{Statistical analyses}

The recorded data of the growth traits were analyzed by PROC MIXED (SAS, 2011) to calculate the generation, line and sex specific means using the following model:

$\mathrm{Y}_{\mathrm{ijklm}}=\mu+\mathrm{a}_{\mathrm{i}}+\mathrm{G}_{\mathrm{j}}+\mathrm{L}_{\mathrm{k}}+\mathrm{S}_{1}+\mathrm{G}_{\mathrm{j}} \mathrm{xL_{ \textrm {k } }}+\mathrm{G}_{\mathrm{i}} \mathrm{X} \mathrm{S}_{1}$ $+\mathrm{L}_{\mathrm{k}} \mathrm{x} \mathrm{S}_{1}+\mathrm{G}_{\mathrm{j}} \mathrm{LL}_{\mathrm{k}} \mathrm{x} \mathrm{S}_{1}+\mathrm{e}_{\mathrm{ijk} k \mathrm{~m}}$

where:

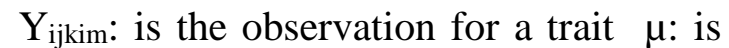
the overall mean, a: is the random additive genetic effect of the $i^{\text {th }}$ animal, $\mathrm{G}$ : the effect of $\mathrm{j}^{\text {th }}$ generation, $\mathrm{L}$ : the effect of $\mathrm{k}^{\text {th }}$ line, $\mathrm{S}$ : the effect of $\mathrm{l}^{\text {th }}$ sex, $G_{j} x L_{k}$ : the effect of interaction of the $j^{\text {th }}$ generation with the $k^{\text {th }}$ line, $G_{j} \times S_{l}$ : the 


\section{A. M. Semida ${ }^{1}$ et al.}

effect of interaction of the $\mathrm{j}^{\text {th }}$ generation with the $1^{\text {th }}$ sex, $L_{k} \times S_{1}$ : : the effect of $k^{\text {th }}$ line with the $1^{\text {th }}$ sex, $G_{j} \times L_{k} \times S_{1}$ : the effect of interaction of the $\mathrm{j}^{\text {th }}$ generation with the $\mathrm{k}^{\text {th }}$ line with the $1^{\text {th }}$ sex and

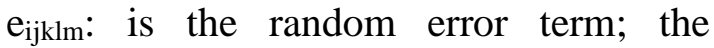
random variable was the birds within line. Means of generation were compared using multiple range test (Duncan, 1955).

Data of plasma constituents, carcass characteristics and chemical composition of carcass traits were analyzed by PROC MIXED (SAS, 2011) to calculate the line and sex specific means by the following model:

$\mathrm{Y}_{\mathrm{ijk} \mathrm{k}}=\mu+\mathrm{a}_{\mathrm{i}}+\mathrm{L}_{\mathrm{j}}+\mathrm{S}_{\mathrm{k}}+\mathrm{L}_{\mathrm{j}} \mathrm{X} \mathrm{S}_{\mathrm{k}}+\mathrm{e}_{\mathrm{ijk} \mathrm{l}}$

where:

$Y_{\mathrm{ijk}}$ : is the observation for a trait $\mu$ : is the overall mean, a: is the random additive genetic effect of the $i^{\text {th }}$ animal, $\mathrm{L}$ : the effect of $j^{\text {th }}$ line, $S$ : the effect of $k^{\text {th }}$ sex, $L_{j}$ $x S_{k}$ : the effect of $j^{\text {th }}$ line with the $k^{\text {th }}$ sex and $e_{i j k l}$ is the random error term; the random variable was the birds within line.

Genetic Parameters:

Both univariate and bivariate linear animal models used to estimate heritabilities $\left(\mathrm{h}^{2}\right)$ of studied traits and correlations. (REML procedures by WOMBAT program software, Meyer, 2007) as follows:

The univariate model to estimate direct $\mathrm{h}^{2}$ was:

$\mathrm{y}=\mathrm{Xb}+\mathrm{Za}+\mathrm{e}$

The bivariate model to estimate correlations between selection criteria trait and other studied traits was:

$\left[\begin{array}{l}y_{1} \\ y_{2}\end{array}\right]=\left[\begin{array}{cc}x_{1} & 0 \\ 0 & x_{2}\end{array}\right]\left[\begin{array}{l}b_{1} \\ b_{2}\end{array}\right]+\left[\begin{array}{cc}z_{1} & 0 \\ 0 & z_{2}\end{array}\right]\left[\begin{array}{l}a_{1} \\ a_{2}\end{array}\right]+$

$\left[\begin{array}{l}e_{1} \\ e_{2}\end{array}\right]$

where: for trait $\mathrm{i}(\mathrm{i}=1,2), \mathrm{y}_{\mathrm{i}}=$ vector of observations, $b_{i}=$ vector of fixed effects (i.e., generation and line, $\mathrm{a}_{\mathrm{i}}=\mathrm{vector}$ of random direct genetic effects, $\mathrm{e}_{\mathrm{i}}=$ vector of random residual effects, and $\mathrm{X}_{\mathrm{i}}$ and $\mathrm{Z}_{\mathrm{i}}$ are incidence matrices relating the observations to the respective fixed and direct genetic effects. Genetic gain:

Genetic gain evaluation depending on breeding values (EBV's) for the studied traits through a mixed model method (Henderson, 1973), by determining the difference between the averages of the EBV's of the first and the last generation within each line separately.

\section{RESULTS AND DISCUSSION}

\section{Selection criteria}

\section{Generation effect:}

Selection criterion $\left(\mathrm{GR}_{1-21}\right)$ significantly increased as generation number increased, the $\mathrm{G}_{4}$ had the fastest whereas, the $G_{1}$ showed the slowest $G_{1-21}(1.77$ vs 1.70) indicated that $G_{4}$ surpassed the $G_{1}$ by $+4.118 \%$ (Table 2). Also, Abdel Fattah (2006) recorded the same trend of GR's which increased after three generations of selection for high GR during the period from one to 42 days of age.

\section{Line effect:}

Line significantly affected $\mathrm{GR}_{1-21}$ $(\mathrm{P} \leq 0.0071)$ favoring the selected line which exceeded the CL by +0.05 $(+2.941 \%)$ as shown in Table 2. This improvement of growth by selection may be due to moderate to high estimates of heritability for GR (Narinc et al., 2014 and Manaa et al., 2015), association with alteration in hormone concentration such as growth hormone and thyroxin due to physiological role of liptin in growth regulation by controlling food intake and thermo genesis through actions on hypothalamic centers as well as its role in energy expenditure and maturity (Peebles and Marks, 1991 and Tartaglia et al., 1995). Regardless of selection criteria, 
selection, early growth rate, carcass characteristics, genetic gain and Japanese quail.

calculated averages for $\mathrm{GR}_{1-21}$ of selected line $\mathrm{GR}_{1-42}$ were $1.71,1.68,1.69$ and 1.70 vs $1.71,1.66,1.69$ and1.69 in CL at base, first, second and third generation, respectively (Abdel Fattah , 2006).

Sex effect:

Sex affected $\mathrm{GR}_{1-21}(\mathrm{P} \leq 0.8208)$ favoring males which surpassing females by +0.02 $(+1.156 \%)$ as shown in Table 2 . This may be due to higher metabolic rate in males or occurred as a result of performance of male sexual activities due to hormonal change (Selim et al., 2006). Conversely, calculated GR 1-21 indicated that females had faster $\mathrm{GR}_{1-21}$ than males (Abdel Fattah, 2006)

\section{Performance of growth traits:}

Generation effects on growth traits:

Generation of selection significantly affected all growth traits. The $4^{\text {th }}$ generation of selection had the best $\mathrm{BW}_{21}, \mathrm{BW}_{35}, \mathrm{BWG}_{1-35}$ and $\mathrm{GR}_{1-35}$ except for $\mathrm{BW}_{1}$. The $1^{\text {st }}$ generation had the lowest $\mathrm{BW}_{1}(7.84, \mathrm{~g})$, the $2^{\text {nd }}$ generation showed lower BW at 35 days of age and Gain $_{1-35}$ being 186.45g and 177.74, respectively whereas the lowest $\mathrm{BW}_{21}$ and $\mathrm{GR}_{1-35}$ were obtained for the $3^{\text {rd }}$ generation (Table 2). Similarly there were significant differences due to generation effect for BW's from hatching up to 21 days (Emam, 2015 and Meabed, 2015).

\section{Line effects on growth traits:}

The effect of short-term selection (4 generations) for $\mathrm{GR}_{1-21}$ on all growth traits was found significant. The $\mathrm{HGR}_{1-21}$ line had better performance for $\mathrm{BW}_{21}$, $\mathrm{BW}_{35}, \mathrm{GR}_{1-35}$ and $\mathrm{BWG}_{1-35}$ than the $\mathrm{CL}$, whereas the $\mathrm{CL}$ had heavier $\mathrm{BW}_{1}$ than HGR $_{1-21}$ line. Also, there were significant higher BW's favoring the selected line, however, the selected line had significantly higher $\mathrm{BW}_{1}$ than the $\mathrm{CL}$ (Narendra Nath et al., 2011). Regardless of generation, selected lines for BW had significantly heavier $\mathrm{BW}_{35}$ than the control line (Taskin et al., 2017).

\section{Sex effects on growth traits:}

Females had significantly higher $\mathrm{BW}_{21}$, $\mathrm{BW}_{35}, \mathrm{BWG}_{1-35}$ and $\mathrm{GR}_{1-35}$ than males. On the other hand, BW at hatch and $\mathrm{GR}_{1-}$ 21 insignificantly favored males regardless of line and generation of selection as shown in Table 2. Results of Narinc et al. (2014) and Elkomy et al. (2019) indicated that females were consistently heavier than males for BW at different ages. In addition, there was significant sexual dimorphism of Japanese quail BW favoring females than its counterpart males which occurred as a result of male sexual activities due to the hormonal change. Similarly, Taskin et al. (2017) indicated that sex was a significant source of variation for $\mathrm{BW}$ at all the ages across selection generations. Similarly, calculated $\mathrm{GR}_{1-35}$ indicated that females had faster GR than males (Daikwo et al., 2014)

Performance of some plasma constituent traits:

Line effect on plasma constituent traits:

As shown in Table3, quails of the selected line had significantly and unpreferably lower HDL (good cholesterol) and higher TG whereas both LDL and total cholesterol were insignificantly differed than the CL. Similarly, significant differences due to line effect were found for TG and cholesterol, the longer shank length at 28 days of age had higher concentrations of TG than other lines (Farahat et al., 2018).

Sex effect on plasma constituent traits: Females had significantly higher TG and lower HDL than males whereas, sex insignificantly affected each of LDL and total cholesterol. Farahat et al. (2018) found that sex had insignificant effects on 


\section{A. M. Semida ${ }^{1}$ et al.}

TG and cholesterol. Moreover, a high level of lipids in the plasma is also an indicator of the great needs of the growing oocytes for yolk lipids (Sato et al., 2004).

Performance of some carcass traits:

Line effect on carcass traits:

Quails of the selected line significantly had higher carcass \%, dressing \%, weights of giblets, heart, gizzard and liver $(+3.65 \%,+2.59,23.79,68.42,13.21$ and $23.47 \%$ respectively) than the $\mathrm{CL}$ as shown in Table 4. Similar trend of significant line effect on carcass $\%$ was reported by Mahmoud et al. (2018). However, Khaldari et al. (2010) reported insignificant differences due to lines for carcass\%. Similarly, Alkan et al. (2010) reported that line insignificantly affected carcass\%. Selection for high $\mathrm{BW}_{42}$ and $\mathrm{GR}_{1-42}$ significantly improved carcass $\%$, dressing $\%$ and boneless meat $\%$ of Japanese quail, also the $\mathrm{HGR}_{1-42}$ line had higher carcass\%, dressing\% and BLM\% than other lines as reported by Mahmoud (2006). Mahmoud et al. (2018) found significant differences due to lines for dressing $\%$.

\section{Sex effect on carcass traits:}

Females had higher weights of giblets, gizzard and liver than their counterparts males by $+12.41 \%,+14.64 \%$ and $+12.34 \%$ whereas, BLM insignificantly affected by sex (Table 3). Males had significantly higher carcass $\%$ and dressing \%, $\quad(+4.00$ and $+2.87 \%$, respectively). Similarly, there were significant effects on carcass\% due to sex (Alkan et al., 2010 and Pourtorabi et al., 2017). This may be due to anatomical differences (sexual organs) between males and females that increase as they approach the age of sexual maturity (early in Japanese quail).
Performance of chemical composition of carcass traits:

Line effect on chemical composition of carcass traits:

Unfortunately, the selected line had higher ether extract \% (+24. 28\%) whereas, had lower moisture\% (-4.79\%) than the CL (Table 5). Similarly, there were significant effects on ether extract \% due to line whereas, insignificantly affected protein $\%$ as reported by Mahmoud (2006).

Sex effect on chemical composition of carcass traits:

Sex had no significant effect on all chemical composition of carcass traits. Similarly, Mahmoud (2006) reported that sex insignificantly affected Ether extract $\%$ and protein $\%$.

Genetic parameters for the studied growth traits:

Heritability $\left(h^{2}\right)$ of selection criteria GR1-21

The GR $_{1-21}$ had medium $\mathrm{h}^{2} 0.28$ (Table $6)$. The results of $h^{2}$ are in agreement with those reported by Abdel Fattah (2006) who found that $\mathrm{h}^{2}$ estimates of $\mathrm{GR}_{1-21}$ were $0.21,0.19$ and 0.20 based on sire, dam and sire + dam variance component in base population, respectively.

Heritability, genetic and phenotypic correlations between GR 1-21 and growth traits:

Genetically, $\mathrm{h}^{2}$ for BW's at different ages showed moderate $h^{2}$ ranged from 0.25 to 0.29 . The $\mathrm{BW}_{1}$ had higher $\mathrm{h}^{2}$ of 0.29 whereas, $\mathrm{BW}_{21}$ showed lower $\mathrm{h}^{2}$ of 0.25 than other BW's, both $\mathrm{GR}_{1-35}$ and $\mathrm{BWG}_{1-}$ 35 had moderate $h^{2}$ of 0.20 (Table 6). Heritability estimates for BWs of this work were in agreement with the reports of other studies concerning $\mathrm{BW}_{1}$ (Sezer et al., 2006), $\mathrm{BW}_{21}$ (Silva et al., 2013) and $\mathrm{BW}_{35}$ (Barbieri et al., 2015). However, $\mathrm{h}^{2}$ estimates of the this study were lower 
selection, early growth rate, carcass characteristics, genetic gain and Japanese quail.

than those reported by several authors $\mathrm{BW}_{1}, \mathrm{BW}_{21}$ (Silva et al., 2013) and $\mathrm{BW}_{35}$ (Sezer et al., 2006).Conversely, $\mathrm{h}^{2}$ for $\mathrm{BW}_{1}$ and $\mathrm{BW}_{35}$ were low $(0.07$ and 0.03 , $\mathrm{BW}_{1}$ ) as reported by Saatci et al. (2006) and Barbieri et al. (2015) and $\mathrm{h}^{2}$ for $\mathrm{BW}_{35}$ being 0.13 (Saatci et al., 2006). The results of Narinc et al. (2014) found moderate $\mathrm{h}^{2}$ for $\mathrm{GR}_{1-35}$ being 0.29 . This wide range of estimates could be due to the differences in populations, method of estimation and statistical models.

The $\mathrm{GR}_{1-21}$ found to be positively correlated with $\mathrm{BW}_{21}, \mathrm{BW}_{35}, \mathrm{BWG}_{1-35}$ and $\mathrm{GR}_{1-35}$, with rgs ranged from 0.24 to 0.70 and $r_{p}$ ranged from 0.03 to 0.41 , however there were negative $r_{g}$ and $r_{p}$ between $\mathrm{GR}_{1-21}$ and $\mathrm{BW}$ being -0.15 and -0.50 , respectively was found as shown in Table 6. Similarly, $r_{g}$ and $r_{p}$ correlations between $\mathrm{GR}_{1-21}$ and $\mathrm{BW}_{1}$ were negative ranged from -0.41 to -0.47 (Abdel Fattah, 2006). Genetic correlations can arise in several ways, they can be caused by pleiotropic gene effect, linkage, pleiotropic occurs when one locus affects multiple traits (Falconer, 1989). Selection based on growth rate, body weights and skeletal measurement traits could increase growth traits of quail (Abdel Fattah, 2006, Emam 2015 and Meabed 2015) due to the expected positive rgs among these traits.

\section{Genetic gain:}

Response showed superiority of the selected line than the control $(P<0.05)$ for selection criteria $(+0.04)$. Selection for $\mathrm{GR}_{1-21}$ had favorable genetic gain with all growth traits, except $\mathrm{BW}_{1}$. Genetic gain estimates indicated insignificant and positive differences for all studied traits whereas, significant differences for $\mathrm{BW}_{1}$ and $\mathrm{BW}_{21}$ were -1.16 and +6.80, respectively. Also, Emam (2015) reported significant genetic gain for BW from hatch up to 35 days of age which ranged from 0.03 to 4.07 in selected line for $\mathrm{BW}_{3}$ under normal diet line and from -0.05 to 8.65 in selected line for $\mathrm{BW}_{3}$ under restricted protein diet line. Meabed (2015) found very highly significant genetic gain for $\mathrm{BW}_{1}, \mathrm{BW}_{21}$ and $\mathrm{BW}_{35}$ being $+0.37,+14.93$ and +12.51 .in longer shank length at 28 days of age and $-0.12,+15.85$ and +18.14 ,respectively in shorter shank length at 28 days of age. In addition Abdel Fattah (2006) found inconsistent change -0.04 to $+0.04 \%$ and -0.01 to $+0.03 \%$ in $\mathrm{GR}_{1-21}$ due to selection for high $\mathrm{BW}_{42}$ and high $\mathrm{GR}_{1-42}$.

\section{CONCLUSION}

Selection for high growth rate during the period from 1 to 21 days of age in Japanese quail improves growth traits especially at marketing age $\left(\mathrm{BW}_{35}\right)$, carcass characteristics and vital organs (carcass \%, dressing \%, weights of giblets, heart, gizzard and liver) were improved by the selection for high growth rate. Selection for $\mathrm{GR}_{1-21}$ had desired genetic gain with most studied growth traits $\left(\mathrm{BW}_{21}, \mathrm{BW}_{35}, \mathrm{BWG1}-35\right.$ and $\left.\mathrm{GR}_{1-35}\right)$ and there were positive $r_{g}$ and $r_{p}$ correlations between $\mathrm{GR}_{1-21}$ and studied growth traits, therefore indirect selection could be used to enhance these traits. 
D. A. M. Semida ${ }^{1}$ et al.

Table (1): Population size over the six generations of the selection experiment.

\begin{tabular}{|l|l|l|l|l|l|}
\hline Generation & Line & Progeny & Sires & Dams & Total \\
\hline Pre-base & - & 1300 & 200 & 400 & 1300 \\
Base & - & 1726 & 132 & 264 & 1726 \\
\hline First & Control line & 454 & 70 & 139 & 1813 \\
& Selected line & 1359 & 89 & 178 & \\
\hline Second & Control line & 456 & 48 & 96 & 1594 \\
& Selected line & 1138 & 86 & 172 & \\
\hline Third & Control line & 472 & 40 & 80 & 1768 \\
& Selected line & 1296 & 90 & 180 & \\
\hline Fourth & Control line & 440 & 68 & 136 & 1823 \\
& Selected line & 1383 & 88 & 176 & \\
\hline Total & & & & & 10,024 \\
\hline
\end{tabular}

Table (2): Least square means \pm SE for the growth traits as affected by generation, line and sex effects.

\begin{tabular}{|c|c|c|c|c|c|c|}
\hline Item & GR $_{1-21}$ & BW $_{1}$ & $\mathrm{BW}_{21}$ & $\mathrm{BW}_{35}$ & BWG $_{1-35}$ & GR $_{1-35}$ \\
\hline \multicolumn{7}{|l|}{$\begin{array}{l}\text { Generation effect } \\
\text { (G): }\end{array}$} \\
\hline $\mathrm{G}_{1}$ & $1.70 \pm 0.001^{\mathrm{d}}$ & $7.84 \pm 0.06^{c}$ & $121.80 \pm 1.01^{\mathrm{b}}$ & $197.11 \pm 1.35^{b}$ & $189.26 \pm 1.34^{\mathrm{b}}$ & $1.85 \pm 0.002^{\mathrm{a}}$ \\
\hline $\mathrm{G}_{2}$ & $1.74 \pm 0.002^{c}$ & $8.71 \pm 0.04^{b}$ & $106.80 \pm 0.71^{c}$ & $186.45 \pm 0.91^{\mathrm{c}}$ & $177.74 \pm 0.92^{c}$ & $1.82 \pm 0.001^{\mathrm{b}}$ \\
\hline $\mathrm{G}_{3}$ & $1.75 \pm 0.002^{b}$ & $9.13 \pm 0.04^{\mathrm{a}}$ & $106.44 \pm 0.71^{\mathrm{c}}$ & $188.22 \pm 0.91^{\mathrm{c}}$ & $179.14 \pm 0.91^{\mathrm{c}}$ & $1.81 \pm 0.001^{\mathrm{c}}$ \\
\hline $\mathrm{G}_{4}$ & $1.77 \pm 0.002^{\mathrm{a}}$ & $7.95 \pm 0.05^{\mathrm{c}}$ & $132.50 \pm 0.88^{\mathrm{a}}$ & $205.46 \pm 1.16^{\mathrm{a}}$ & $197.29 \pm 1.15^{\mathrm{a}}$ & $1.85 \pm 0.002^{\mathrm{a}}$ \\
\hline \multicolumn{7}{|c|}{. } \\
\hline $\mathrm{CL}$ & $1.70 \pm 0.003^{b}$ & $8.63 \pm 0.04^{\mathrm{a}}$ & $107.63 \pm 0.73^{b}$ & $185.22 \pm 0.96^{\mathrm{b}}$ & $176.81 \pm 0.96^{\mathrm{b}}$ & $1.81 \pm 0.003^{b}$ \\
\hline HGR1-21 & $1.75 \pm 0.001^{\mathrm{a}}$ & $8.51 \pm 0.03^{b}$ & $116.62 \pm 0.41^{\mathrm{a}}$ & $194.93 \pm 0.53^{\mathrm{a}}$ & $186.33 \pm 0.53^{\mathrm{a}}$ & $1.83 \pm 0.001^{\mathrm{a}}$ \\
\hline \multicolumn{7}{|l|}{ Sex effect: } \\
\hline Female & $1.73 \pm 0.001$ & $8.55 \pm 0.03$ & $117.08 \pm 0.64^{\mathrm{a}}$ & $198.72 \pm 0.76^{\mathrm{a}}$ & $190.19 \pm 0.76^{\mathrm{a}}$ & $1.83 \pm 0.001^{\mathrm{a}}$ \\
\hline Male & $1.75 \pm 0.003$ & $8.52 \pm 0.04$ & $111.85 \pm 0.67^{b}$ & $186.27 \pm 0.79^{b}$ & $177.73 \pm 0.79^{b}$ & $1.82 \pm 0.002^{b}$ \\
\hline \multicolumn{7}{|l|}{$p$-value } \\
\hline Generation & 0.0001 & 0.0001 & 0.0001 & 0.0001 & 0.0001 & 0.0001 \\
\hline Line & 0.0071 & 0.0071 & 0.0001 & 0.0001 & 0.0001 & 0.0001 \\
\hline Sex & 0.8208 & 0.4621 & 0.0001 & 0.0001 & 0.0001 & 0.0001 \\
\hline Generation*Line & 0.6493 & 0.0001 & 0.0015 & 0.3902 & 0.0946 & 0.0001 \\
\hline Generation*Sex & 0.5489 & 0.0801 & 0.7124 & 0.0634 & 0.2468 & 0.8406 \\
\hline Line*Sex & 0.0700 & 0.3268 & 0.5106 & 0.5893 & 0.5841 & 0.6123 \\
\hline Generation*Line $*$ Sex & 0.5814 & 0.5163 & 0.8144 & 0.7412 & 0.6541 & 0.5355 \\
\hline
\end{tabular}

Means having different superscripts within each effect in the same column are significantly differed at specified probability, SE: stander error, $\mathrm{BW}_{1}, \mathrm{BW}_{21}$ and $\mathrm{BW}_{35}$ : body weights at hatch, 21 and 35 days of age respectively, $\mathrm{BWG}_{1-35}$ : body weight gain during the periods from 1-35 days of age, $\mathrm{GR}_{1-21}$ and $\mathrm{GR}_{1-35}$ : growth rates during the periods from 1-21 and 1-35 days of age, $\mathrm{HGR}_{1-21}$ : the selected line for high growth rate during 1-21 days of age, CL: the control line, P: Probability. 
selection, early growth rate, carcass characteristics, genetic gain and Japanese quail.

Table (3): Least square means \pm SE for the some plasma constituent traits as affected by line, sex and line $\mathrm{x}$ sex effects

\begin{tabular}{|l|c|c|c|c|}
\hline Item & HDL, mg/dl & LDL, mg/dl & Total cholesterol, mg/dl & TG, mg/dl \\
\hline $\begin{array}{l}\text { Line } \\
\text { effect: }\end{array}$ & \multicolumn{5}{|l|}{} \\
\hline CL & $44.71 \pm 1.20^{\mathrm{a}}$ & $116.15 \pm 7.36$ & $193.44 \pm 9.59$ & $179.52 \pm 11.33^{\mathrm{b}}$ \\
HGR $_{1-21}$ & $36.72 \pm 1.22^{\mathrm{b}}$ & $135.75 \pm 7.45$ & $214.50 \pm 9.47$ & $256.96 \pm 12.84^{\mathrm{a}}$ \\
\hline Sex effect: & \multicolumn{5}{|c|}{} \\
\hline Female & $38.87 \pm 1.17^{\mathrm{b}}$ & $126.50 \pm 7.18$ & $210.38 \pm 9.24$ & $266.04 \pm 12.47^{\mathrm{a}}$ \\
Male & $42.55 \pm 1.24^{\mathrm{a}}$ & $124.74 \pm 7.62$ & $196.26 \pm 9.81$ & $169.89 \pm 11.74^{\mathrm{b}}$ \\
\hline $\boldsymbol{p}$-value & \multicolumn{5}{|l}{} \\
\hline Line & 0.0001 & 0.0649 & 0.1238 & 0.0001 \\
Sex & 0.0366 & 0.8670 & 0.2993 & 0.0001 \\
Line $^{*}$ Sex & 0.0394 & 0.5720 & 0.3301 & 0.0001 \\
\hline
\end{tabular}

Means having different superscripts within each effect in the same column are significantly differed at specified probability, SE: stander error, HDL: high density lipoprotein, LDL: low density lipoprotein and TG: triglycerides, $\mathrm{HGR}_{1-21}$ : the selected line for high growth rate during 1-21 days of age, CL: the control line, P: Probability.

Table (4): Least square means \pm SE for carcass traits as affected by line, sex and line $\mathrm{x}$ sex effects

\begin{tabular}{|c|c|c|c|c|c|c|c|}
\hline \multirow[t]{2}{*}{ Item } & \multicolumn{3}{|c|}{ Percentages } & \multicolumn{4}{|c|}{ Weights } \\
\hline & Carcass \% & Dressing \% & BLM\% & Giblets, $\mathrm{g}$ & Heart, g & Gizzard, $\mathrm{g}$ & Liver, $\mathrm{g}$ \\
\hline \multicolumn{8}{|c|}{ Line effect: } \\
\hline $\mathrm{CL}$ & $67.04 \pm 1.55^{\mathrm{b}}$ & $73.70 \pm 1.60^{b}$ & $49.37 \pm 0.87$ & $11.81 \pm 1.13^{b}$ & $1.33 \pm 0.08^{\mathrm{b}}$ & $5.22 \pm 0.12^{\mathrm{b}}$ & $5.24 \pm 0.27^{b}$ \\
\hline $\mathrm{HGR}_{1-21}$ & $69.49 \pm 1.36^{\mathrm{a}}$ & $75.61 \pm 1.42^{\mathrm{a}}$ & $50.51 \pm 0.82$ & $14.62 \pm 0.85^{\mathrm{a}}$ & $2.24 \pm 0.06^{\mathrm{a}}$ & $5.91 \pm 0.16^{\mathrm{a}}$ & $6.47 \pm 0.19^{\mathrm{a}}$ \\
\hline \multicolumn{8}{|c|}{ Sex effect: } \\
\hline Female & $67.32 \pm 1.17^{b}$ & $73.91 \pm 1.24^{b}$ & $49.37 \pm 0.82$ & $14.40 \pm 0.88^{\mathrm{a}}$ & $1.77 \pm 0.07$ & $5.95 \pm 0.14^{\mathrm{a}}$ & $6.19 \pm 0.23^{\mathrm{a}}$ \\
\hline Male & $70.01 \pm 1.74^{\mathrm{a}}$ & $76.03 \pm 1.77^{\mathrm{a}}$ & $50.51 \pm 0.82$ & $12.81 \pm 1.10$ & $1.79 \pm 0.07$ & $5.19 \pm 0.15^{\mathrm{b}}$ & $5.51 \pm 0.24^{\mathrm{b}}$ \\
\hline \multicolumn{8}{|l|}{$p$-value } \\
\hline Line & 0.0052 & 0.0334 & 0.2984 & 0.0001 & 0.0001 & 0.0012 & 0.0004 \\
\hline Sex & 0.0014 & 0.0139 & 0.7579 & 0.0018 & 0.8823 & 0.0004 & 0.0432 \\
\hline Line*Sex & 0.0011 & 0.0038 & 0.3409 & 0.0414 & 0.7872 & 0.0132 & 0.3084 \\
\hline
\end{tabular}

Means having different superscripts within each effect in the same column are significantly differed at specified probability, SE: stander error, BLM: boneless meat, $\mathrm{HGR}_{1-21}$ : the selected line for high growth rate during 1-21 days of age, CL: the control line, P: Probability. 


\section{A. M. Semida ${ }^{1}$ et al.}

Table (5): Least square means \pm SE for chemical composition of carcass as affected by line, sex and line $\mathrm{x}$ sex effects

\begin{tabular}{|l|l|l|l|l|}
\hline Item & Protein \% & $\begin{array}{l}\text { Ether extract } \\
\%\end{array}$ & Ash\% & Moisture \% \\
\hline Line effect: & \multicolumn{5}{|l|}{} \\
\hline CL & $22.74 \pm 0.43$ & $3.13 \pm 0.16^{\mathrm{b}}$ & $1.98 \pm 0.10$ & $69.67 \pm 0.50^{\mathrm{a}}$ \\
HGR $_{1-21}$ & $23.78 \pm 0.44$ & $3.89 \pm 0.17^{\mathrm{a}}$ & $2.18 \pm 0.11$ & $66.33 \pm 0.52^{\mathrm{b}}$ \\
\hline Sex effect: & \multicolumn{5}{|l}{} \\
\hline Female & $22.97 \pm 0.41$ & $3.54 \pm 0.17$ & $1.97 \pm 0.11$ & $68.31 \pm 0.52$ \\
Male & $23.16 \pm 0.44$ & $3.47 \pm 0.16$ & $2.19 \pm 0.10$ & $67.68 \pm 0.51$ \\
\hline $\boldsymbol{p}$-value & \multicolumn{5}{|l}{} \\
\hline Line & 0.2958 & 0.0016 & 0.1901 & 0.0001 \\
Sex & 0.7603 & 0.7592 & 0.1467 & 0.3885 \\
Line*Sex & 0.7273 & 0.8605 & 0.3053 & 0.8096 \\
\hline
\end{tabular}

Means having different superscripts within each effect in the same column are significantly differed at specified probability, SE: stander error, $\mathrm{HGR}_{1-21}$ : the selected line for high growth rate during 1-21 days of age, CL: the control line, P: Probability.

Table (6): Heritability, genetic gain, genetic and phenotypic correlations $\pm \mathrm{SE}$ of $\mathrm{R}_{1-21}$ and some growth traits.

\begin{tabular}{|l|c|c|c|c|}
\hline \multicolumn{1}{|c|}{ Trait } & $\mathbf{h}^{2} \pm$ SE & Genetic gain & rg \pm SE & rp \pm SE \\
\hline $\mathrm{GR}_{1-21}$ & $0.28 \pm 0.005$ & $+0.04 \pm 0.01^{*}$ & & \\
$\mathrm{BW}_{1}$ & $0.29 \pm 0.030$ & $-1.16 \pm 0.03^{* * *}$ & $-0.15 \pm .04$ & $-0.50 \pm 0.02$ \\
$\mathrm{BW}_{21}$ & $0.25 \pm 0.031$ & $+6.80 \pm 0.60^{* *}$ & $0.47 \pm 0.02$ & $0.41 \pm 0.03$ \\
$\mathrm{BW}_{35}$ & $0.26 \pm 0.006$ & $+5.47 \pm 0.87^{\mathrm{ns}}$ & $0.33 \pm 0.10$ & $0.24 \pm 0.03$ \\
$\mathrm{GR}_{1-35}$ & $0.20 \pm 0.004$ & $+0.02 \pm 0.003^{\mathrm{ns}}$ & $0.70 \pm 0.05$ & $0.03 \pm 0.01$ \\
$\mathrm{BWG}_{1-35}$ & $0.20 \pm 0.004$ & $+4.54 \pm 0.79^{\mathrm{ns}}$ & $0.24 \pm 0.03$ & $0.26 \pm 0.03$ \\
\hline
\end{tabular}

$\mathrm{h}^{2}$ : heritability, SE: stander error, rg: genetic correlation, rp: phenotypic correlation, $\mathrm{BW}_{1}, \mathrm{BW}_{21}$ and $\mathrm{BW}_{35}$ : body weights at hatch, 21 and 35 days of age respectively, $\mathrm{BWG}_{1-35}$ : body weight gain during the periods from 1-35 days of age, $\mathrm{GR}_{1-21}$ and $\mathrm{GR}_{1-35}$ : growth rates during the periods from 1-21 and 1-35 days of age, ns: non-significant, ***,***: significant at levels 0.05 , $0.01,0.001$ respectively. 
selection, early growth rate, carcass characteristics, genetic gain and Japanese quail.

\section{REFERENCES}

Abdel Fattah, M. H. 2006. Selection for increased body weight and growth rate in Japanese quail. Ph. D. Thesis, Fac. Agric., Fayoum Univ., Egypt.

Alkan S, Karabag, K. , Galic, A. , Karsli, T. and Balcioglu, M. S. 2010. Determination of body weight and some carcass traits in Japanese quails (Cortunix cortunix japonica) of different lines. Kafkas Üniversitesi Veteriner Fakültesi Dergisi 16, 277280.

Anthony, N. B., Emmerson, D. A., Nestor, K. E., Bacon, W. L., Siegel, P. B. and Dunnington, E.A. 1991. Comparisons of growth curves of weight selected populations of turkeys, quail and chickens. Poult. Sci., 70: 13-19.

Barbieri, A. , Ono, R. K. , Cursino, L. L., Farah, M. M. , Pires, M. P. , Bertipaglia, T. S., Pires, A.V., Cavani, L., Carreño, L. O. D. and Fonseca, R. 2015. Genetic parameters for body weight in meat quail. Poult. Sci. 94: 169-171.

Brody, S. 1945. Bioenergetics and Growth. Reinhold Publishing Corp., New York, NT.

Daikwo, S. I., Dim, N. I. and Momoh, O. M. 2014.Genetic parameters of some Egg Production traits in Japanese quail in a tropical Environment. Journal of Agriculture and Veterinary Science. Volume 7, Issue 9 Ver. III, PP 39-42.

Druyan, S., Ben-David, A. and Cahaner, A. 2007. Development of ascites-resistant and ascitessusceptible broiler lines. Poultry Science 86:811-822.

Duncan, D. B. 1955. Multiple range and multiple F-tests. Biometrics, 11: 1-42.
Elkomy, H. E., Taha, A. E., Basha, H. A., Abo-Samaha, M. I., and Sharaf. M. M. 2019. Growth and reproduction performance of Japanese quails (Coturnix coturnix japonica) under various environments of light colors. Slov. Vet. Res., 56 119-127.

Emam, A. M. 2015. Selection for high body weight under two nutritional environments in Japanese quail.. Ph. D. Thesis, Fac. Agric., Fay. Univ., Egypt.

Falconer, D. S., 1989. Introduction to Quantitative Genetics. $3^{\text {rd }}$ ed, Longman Group, Essex, England.

Farahat, G. S. , Mahmoud, B. Y., ElKomy, E. M. and El-Full, E. A. 2018. Alterations in plasma constituents, growth and egg production traits due to selection in three genotypes of Japanese quail. J. Agric. Sci. 156: 118-126.

Havenstein, G. G., Ferket, P. R., and Qureshi, M. A. 2003. Carcass composition and yield of 1957 versus 2001 broilers when fed representative 1957 and 2001 broiler diets. Poult. Sci. 82:1509-1518.

Henderson, C. R. 1973. Sire evaluation and genetic trends. J. Anim. Sci. 1973, Issue Symposium. 10-41.

Khaldari , M., Pakdel, A. , Yegane, H. M. , Javaremi, A. N. and Berg, P. 2010. Response to selection and genetic parameters of body and carcass weights in Japanese quail selected for 4-week body weight. Poult. Sci. 89 :1834-1841.

Mahmoud B. Y. F. 2006 Relationships among plasma constituents and carcass traits in three lines of Japanese quail differing in genetic 
D. A. M. Semida ${ }^{1}$ et al.

background. M.Sc. Thesis, Fac. Agric., Fayoum Univ., Egypt.

Mahmoud, B. Y., Abdel Hafez, A. S., Emam, A. M., Abdelmoniem, A. M. and El Safty, S. A. 2018. Feathering rate impact on growth and slaughter traits of Japanese quail. J. Agric. Sci. 156: 942-948.

Manaa, E. A., El-Bayomi, K. M. and Sosa, G. A. 2015. Genetic evaluation for growth traits in Japanese quail. Benha Veterinary Medical J, 28, 1:816.

Meabed, S.A.A. 2015. Response to three generation of divergent selection for shank length in Japanese quail. Ph. D. Thesis, Fac. Agric., Fay. Univ., Egypt.

Meyer, K. 2007. WOMBAT: a tool for mixed model analyses in quantitative genetics by restricted maximum likelihood (REML). J. Zhejiang Univ. Sci. B. 8: 815-821.

N.R.C., 1994. Nutrient Requirements of Domestic Animals. Nutrient Requirements of Poultry, 9th Rev. edn. Washington, DC: National Academy Press

Narendra Nath, D. , Sheriff, F. R. , Prabakaran, R. and Asha Rajini, R. 2011. Response to short term index selection for economic traits in meat type Japanese quail. J. Indian Vet. Sci. 9: 10-14.

Narinc, D. and Aksoy, T. 2012.Effects of mass selection based on phenotype and early feed restriction on the performance and carcass characteristics in Japanese quails. Kafkas univ vet Fark Derg 18,3: 425-430.

Narinc, D., Karaman, E., Aksoy, T., and Firat, M. Z. 2014. Genetic parameter estimates of growth curve and reproduction traits in Japanese quail. Poult. Sci. 93:24-30.

Peebles, E. D. and Marks, H. L. 1991. Effect of selection on plasma thyroxine concentrations in Japanese quail under thiouracil and protein stress. Poult. Sci., 70: 641-650.

Pourtorabi, E., Farzin, N. and Seraj, A. 2017. Effects of genetic and nongenetic factors on body weight and carcass related traits in two strains of Japanese quails. Poult. Sci. J. 5 : 1724.

Reddish, M. S. 2004. Evaluation of the effects of selection for increased body weight and increased yield on growth and development of Poult. Ph.D. Thesis. The Ohio state University. USA.

Saatci, M., Omed, H. and Ap Dewi, I. 2006. Genetic parameters from univariate and bivariate analyses of egg and weight traits in Japanese quail. Poult. Sci. 85:185-190.

SAS Institute Inc 2011. SAS/STAT® 9.3 User's Guide. Cary, NC: SAS Institute Inc.

Sato, K., Fukao K., Seki, Y. and Akiba, Y. 2004. Expression of the chicken peroxisome proliferatoractivated receptor-gamma gene is influenced by aging, nutrition and agonist administration. Poult. Sci. 83: 1342-1347.

Selim, K., Ibarhim S. and Ozge Y. (2006). Effect of separate and mixed rearing according to sex on tattering performance and carcass characteristics in Japanese quails (Coturnix coturnix Japonica). Arch Tierz. Dummerstort. 49: 607-614.

Sezer, M., Berberoglu, E., and Ulutas, Z. 2006. Genetic association between sexual maturity and weekly liveweights in laying-type Japanese 
selection, early growth rate, carcass characteristics, genetic gain and Japanese quail.

quail. South. Afric. J. Anim. Sci. 36:142-148.

Silva, L. P. , Ribeiro, J. C., Crispim, A. C. , Silva, F. G., Bonafé, C. M., Fabyano, F. S. and Torres, R. A. 2013. Genetic parameters of body weight and egg traits in meat-type quail. Livestock Science 153: 27-32.

Tartaglia, L. A., Dembski, M., Weng, X., Deng, N., Culpepper, J., Devos, R., Richards, G. J., Campfield, L. A., Clark, C. T., Deeds, J., Muir, C., Sanker, S., Moriarty, A. , Moore, K. J., Smutko, J. S., Mays, G. G., Woolf, E. A., Monroe, C. A. and Tepper, R. I. 1995. Identification and expression cloning of leptin receptor, OB-R. cell, 29: 1263-1271.
Taskin A. , Karadavut, U., Tunca, R. I., Genc, S. and Cayan, H. 2017. Effect of selection for body weight in Japanese quails (Coturnix coturnix Japonica) on some production traits. Indian J. Anim. Res. 51:358-364. 


\title{
D. A. M. Semida ${ }^{1}$ et al.
}

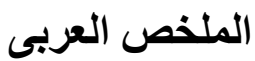

\author{
تأثيرات الاتتخاب لزيادة معدل النمو المبكر على صفات النمو و خصائص الأبيحة في السمان \\ الياباني \\ دعاء عبد الحميد محمود صميده 1،بثينه يوسف فؤاد محمود 1، إنصاف أحمد القل1 و أحمد محمد إمام1 \\ 1 ق ق قسم انتاج الدواجن - كلية الزر اعة - جامعة الفيوم
}

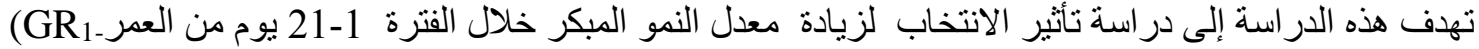

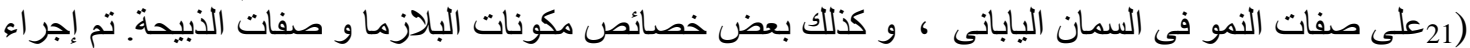

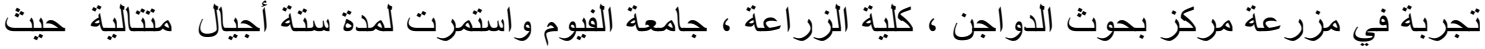
تضمنت على 10,024 طائر من السمان الياباني في خطين (الخط المنتخب،

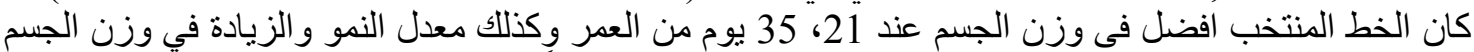

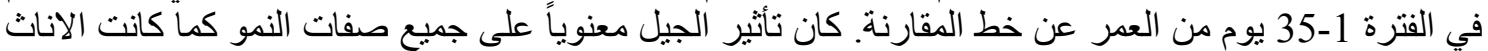

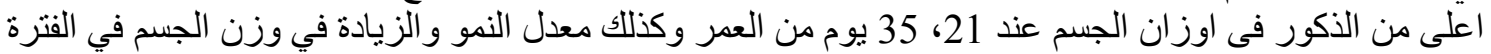

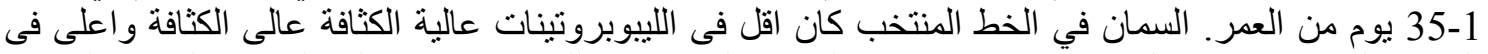

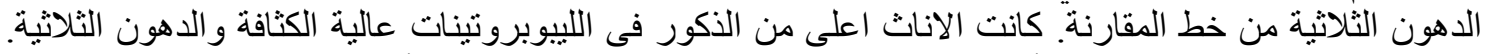

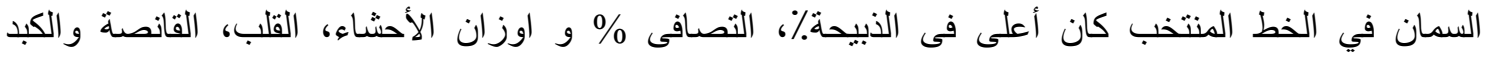

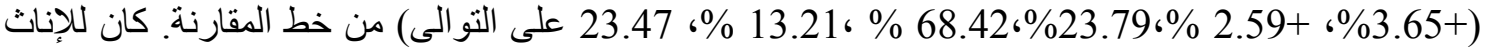

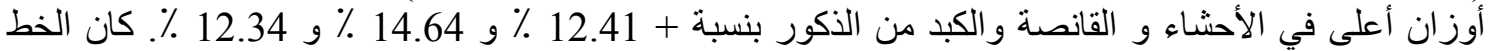

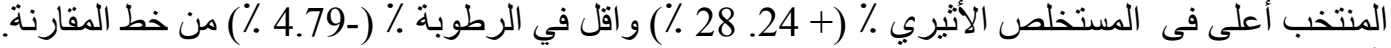

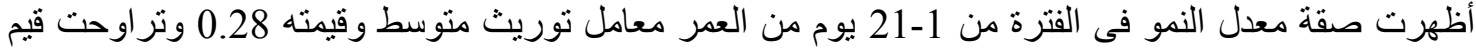

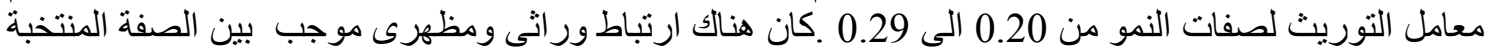

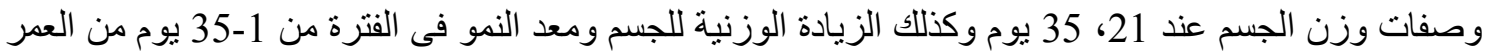

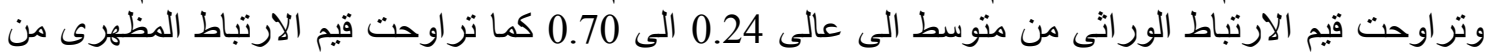

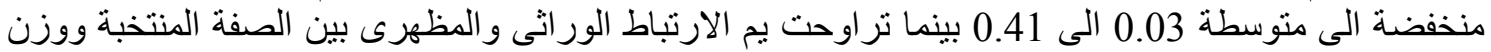

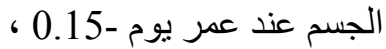

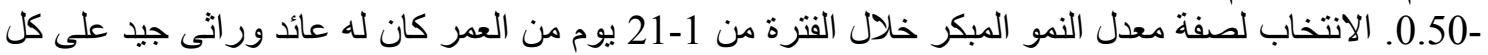

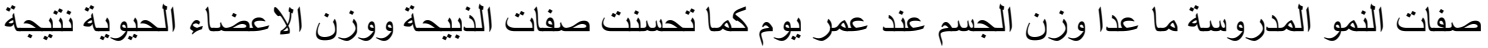

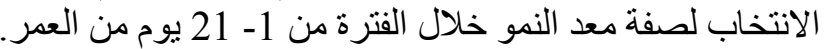

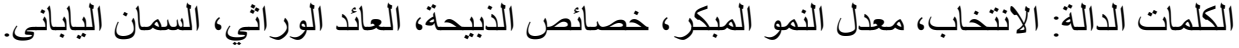

